The Bangladesh Veterinarian (2010) 27(2) : 62 - 73

\title{
Effects of age on intake, growth, nutrient utilization and carcass characteristics of castrated native sheep
}

\author{
N. Sultana $1^{*}$, S. M. J. Hossain, S. A. Chowdhury2, M. R. Hassan and \\ M. Ershaduzzaman \\ Goat and Sheep Production Research Division, Bangladesh Livestock Research Institute, \\ Savar, Dhaka-1341, Bangladesh
}

\begin{abstract}
Twenty four castrated native sheep were grouped (six/group) into four: $\mathrm{T}_{1}>3$ to $\leq 6$; $\mathrm{T}_{2}>6$ to $\leq 9 ; \mathrm{T}_{3}>9$ to $\leq 12$ and $\mathrm{T}_{4}>12$ to $\leq 15$ months. Through out the 63 days of experimental period, animals were offered ad libitum urea (3\%), molasses $(15 \%)$ and straw $(82 \%)$ as a basal diet with concentrate mixture [14\% crude protein $(\mathrm{CP})$ \& $11.5 \mathrm{MJ}$ metabolizing energy (ME) per kg Dry Matter (DM)] @ 1\% of live weight. Five days metabolic trial was conducted towards the end of the feeding trial. Besides, fortnightly live weight change, daily nutrient intake, carcass yield and carcass characteristics were studied. Daily weight gain decreased $(\mathrm{P}<0.05)$ with the increasing in age and the growth rate were $79,63,55$ and $44 \mathrm{~g} /$ day for $\mathrm{T}_{1}, \mathrm{~T}_{2}, \mathrm{~T}_{3}$ and $\mathrm{T}_{4}$, respectively. Higher growth rate in $\mathrm{T}_{1}$ was due to animal's inherent self-accelerated phase of growth. Feed conversion ratio (FCR; kg feed/ $\mathrm{kg}$ live weight gain) was significantly $(\mathrm{P}<0.001)$ better in $\mathrm{T}_{1}(9.2)$ followed by $\mathrm{T}_{2}(13.8), \mathrm{T}_{3}(17.7)$ and $\mathrm{T}_{4}$ (21.7). Cost per $\mathrm{kg}$ of carcass production was lower in $\mathrm{T}_{1}$ (Taka: 239), but the production cost increased in $\mathrm{T}_{2}$ (Taka: 357), $\mathrm{T}_{3}$ (Taka: 440) and $\mathrm{T}_{4}$ (Taka: 515). DM intake $\left(\mathrm{g} / \mathrm{kg} \mathrm{W}^{0.75}\right)$ decreased with the increase in age and weight. For each gram increased in live weight gain, it required $7.7 \mathrm{~kJ} \mathrm{ME}$ and animals achieved zero live weight gain (maintenance energy level) at $377 \mathrm{~kJ} / \mathrm{kg} \mathrm{W}^{0.75} / \mathrm{d}$ ME intake. Slaughtered weight, warmed carcass weight and dressing yield (\%) of native sheep increased with advancement of age. Dressing yields were $48.5,49,51.4$ and 55.5\% for $T_{1}, T_{2}, T_{3}$ and $T_{4}$, respectively. Fat percent increased with increasing age and body fat as percent of live weight were 5.6, 7.7 15.5 and 20.6, respectively for the $\mathrm{T}_{1}, \mathrm{~T}_{2}, \mathrm{~T}_{3}$ and $\mathrm{T}_{4}$. As a part of total carcass, the proportional yield of tender loin and hind leg chump, most valued retail cut, decreased with the increased animal age. In the present trial, body weight gain at early stage (6-8 months of age) of life was more economical than at the later stage of life. It is suggests that the optimum market/slaughter age for native sheep maintained under these feeding and management would be at around eight months of age. (Bangl. vet. 2010. Vol. 27, No. 2, 62 - 73)
\end{abstract}

\section{Introduction}

Sheep are sparsely distributed all over the country, but greater concentration of sheep is in the districts of Rajshahi, Dinajpur, Bogra, Rangpur, Tangail and in the delta region of Noakhali where there are many charlands are available (Rahman,

1 Department of Animal Science, Faculty of Agriculture, University of Putra, Malaysia

2 Palli Karmo Sohayok Foundation, Agargaon, Dhaka, Bangladesh

* Corresponding author. E-mail: nassul2003@yahoo.com 
1989, Hossain et al., 1997). Indigenous sheep is inferior to produce hides and wool (Mukherjee, 2000). Under traditional feeding system; the sheep are raised by grazing on harvested or fellow lands, roads, and canal sides for plane land and char area, almost without concentrate supplementation. Dietary nutrients usually energy and protein are the major important factors affecting meat production in goats and sheep (Shajalal et al., 1992). Growth potential can be exploited by the use of high-energy diet. In Charland, sheep are usually raised on natural grass and take over two years for marketing (personal communication) and hence produces low quality carcass. Concentrate supplementation reduces age to slaughter and increases carcass quality (Mtenga and Kitalyi, 1990). Native sheep are small in size weighing $15-25 \mathrm{~kg}$, mainly reared for meat production (Mukherjee, 2000). Under traditional feeding system without organized input by farmers, the Indian lamb achieved $40-50 \mathrm{~g}$ average daily gain in active phase of growth and marketed for slaughter at 9-12 months of age weighing about 20-22 kg (Singh and Karim, 2003). Age, breed, sex, feed, genotype, management, environment are influencing quantity and quality meat production. After certain age, growth rate of sheep is reduced, which is not economical for farmers. There is a need to establish an appropriate age to obtain good response and avoid expensive fat deposition in the carcass. The present study was designed to determine the effect of age on intake, growth, different nutrient utilization, carcass characteristics and economics of native sheep on marketing age of male castrated sheep, and to know the carcass characteristics at different ages and to analyze the cost benefit at different ages for lamb production.

\section{Materials and Methods}

\section{Experimental animals and management}

The study was carried out for 63 days during December 2008 to February 2009. Twenty four castrated native sheep were selected on the basis of age and were grouped into four: $\mathrm{T}_{1}>3$ to $\leq 6 ; \mathrm{T}_{2}>6$ to $\leq 9 ; \mathrm{T}_{3}>9$ to $\leq 12 ; \mathrm{T}_{4}>12 \leq 15$ months consisting of six animals in each group. The diet was supplied uniformly for all animals. Urea molasses straw ( $3 \%$ urea; molasses $15 \%$, straw $82 \%$ ) was supplied ad libitum with $1 \%$ concentrate containing $\mathrm{CP}$, energy contents of $14 \%$ and $11.5 \mathrm{MJ}$ $\mathrm{ME} / \mathrm{kg} \mathrm{DM}$, respectively. Diets were formulated (Table 1) and offered twice a day 8.00 A.M and 3.00 PM, respectively. Concentrate feed was adjusted weekly with animal's body weight. Fresh water supplied ad libitum. Refusals were weighted before the distribution of morning meal to evaluate DM and other nutrients intake in the following days. Representative sample was taken to laboratory for analysis. A metabolic trial was conducted with five days collection after 53 days of experimental feeding ( 5 castrated male sheep/each group) during the growth period. 


\section{Slaughter procedure and management}

At the end of experimental period, prior to slaughter, different body measurements including shoulder (wither) height at hind legs; chest depth (half of the circumstances of chest girth) and body length (point of elbow to point of hip) were recorded. Five animals from each group were slaughtered according to 'Halal' method by severing the major vessels of the throat by a transverse cut after being fasted for around 24 hours. Fasted live weight was recorded immediately before slaughter. Bleeding, skinning, and evisceration were done as per the standard commercial procedure. The gastrointestinal tract (GI) was weighted with contents and then weight was taken again after removing of internal food material for the determining the exact weight of the GI tract. Dressing percentage was calculated as percentage of hot carcass with the weight of fasting live weight. Non-carcass edible components were removed directly after slaughter, which included lungs and trachea, heart, liver, spleen, kidney, fat and gallbladder. Different primal cuts such as shoulder, tender loin, rack, leg chump, fore shank, hind shank and breast and flaps were done according to AUS-MEAT specification. The sample 100-120g from different primal cut was collected for analyses of moisture, $\mathrm{CP}$, fat and ash.

Table 1. Chemical composition (\%) of UMS and concentrate mixtures

\begin{tabular}{l|c|c}
\multicolumn{1}{c|}{ Items } & UMS & Concentrate \\
\hline Ingredient (\%) & & \\
Maize crush & - & 30.0 \\
Wheat bran & - & 25.0 \\
Kheshery bran & - & 26.0 \\
Till oil cake & - & 15.0 \\
Fish meal & - & 2.0 \\
Salt & - & 1.0 \\
Di-calcium phosphate (DCP) & - & 0.5 \\
Vitamin-mineral premix & - & 0.5 \\
\hline Chemical composition (\%) & & \\
Dry matter (DM) & 61.2 & 91.0 \\
Organic matter (OM) & 84.6 & 89.2 \\
Crude protein (CP) & 8.8 & 14.5 \\
Acid detergent fibre (ADF) & 39.1 & 28.0 \\
Metabolizable energy (MJ/kg DM) & 8.5 & 11.5 \\
\hline
\end{tabular}

Chemical analysis

Feed, feces and refusal were analyzed as per AOAC (1984). Nitrogen in feed, faeces, urine and refusal sample was measured by Kjeldhal method (AOAC, 1984). 
Meat samples from different cuts were analyzed for moisture, ash, $\mathrm{CP}$ and ether extract (EE) according to the AOAC (1984).

\section{Statistical analysis}

Data were subjected to ANOVA for a completely randomized design using the general linear procedure of SPSS (11.0). Average daily gain was determined by linear regression. The significant differences were isolated by Least Significant Differences (LSD).

\section{Results and Discussion}

Chemical composition of feed

The ingredient and chemical compositions of the experimental diets are presented in Table 1. The DM and CP content of Urea Mollasses Straw (UMS) was 61.2 and $8.8 \%$, respectively. The cell wall content in terms of acid detergent fibre (ADF) of UMS was 39.1\% (Table 1). The concentrate mixture used to feed all castrated male was similar.

\section{Body weight gain and cost of feeding}

Initial and final body weights, average daily gain (ADG), FCR and cost of one kg meat production are summarized in Table 2. Average daily weight gain was decreased $(\mathrm{P}<0.05)$ with increasing age on the same plane of nutrition. The growth rate of $\mathrm{T}_{1}, \mathrm{~T}_{2}, \mathrm{~T}_{3}$ and $\mathrm{T}_{4}$ were $79.3,63.3,54.6$ and $44.0 \mathrm{~g} /$ day, respectively. It is shown that the highest growth rate was in $\mathrm{T}_{1}$ and lowest in $\mathrm{T}_{4}$. Our results are supported by Dutta et al. (2007) who got higher body weight $(35.6 \mathrm{~kg})$ at six month of age in Muzafrnagari lamb. Mandal et al. (2000) observed $28.4 \mathrm{~kg}$ body weight of Muzaffarnagari male lambs at six months of age that managed under semi-intensive system. Devendra and McLeroy (1982) stated that younger goats and sheep showed higher growth rate under self-accelerating phase of growth. FCR $[\mathrm{kg}$ feed $/ \mathrm{kg}$ Live Weight $(\mathrm{LW})$ gain] was significantly $(\mathrm{P}<0.001)$ better in the young $\mathrm{T}_{1}(9.2)$ followed by $\mathrm{T}_{2}$ (13.8), $\mathrm{T}_{3}$ (17.7) and $\mathrm{T}_{4}$ (21.7). It indicates that the efficiency of feed conversion of native sheep began within three months of age. The age of $\mathrm{T}_{1}$ was more converters from feed to meat than other three groups (Table 2). The cost of feed per $\mathrm{kg}$ meat production was lower (Taka: $239 / \mathrm{kg}$ meat. $1 \mathrm{US} \$=70 \mathrm{Taka}$ ) in $\mathrm{T}_{1}$ followed by $\mathrm{T}_{2}$ (Taka: 357), $\mathrm{T}_{3}$ (Taka: 440) and $\mathrm{T}_{4}$ (Taka: 515).

\section{Intake}

Daily intake of feed and nutrients by castrated native sheep of different ages is shown in Table 3. Average daily Total DM Intake (TDMI) was significantly $(\mathrm{P}<0.05)$ higher in $T_{3}, T_{2}$ and $T_{4}$ than that of $T_{1}$. TDMI was increased up to $T_{3}$ but decreased in $\mathrm{T}_{4}$. Concentrate percent of DMI was significantly $(\mathrm{P}<0.05)$ higher $(32 \%)$ in the older aged $\left(T_{4}\right)$ than the other three groups. The amount of concentrate as percent of TDM was difference due to UMS, TDMI was decreased with the increasing age. The same result was shown by Huque et al. (2007) in cattle on silage based ration. The DM intake as \% LW was significantly $(\mathrm{P}<0.05)$ lower in the older group compare to other three groups. DM intake as \% LW was declined with increasing age of sheep. This 
result is consistent with Huque et al. (2007). The calculated daily ME and Metabolizable protein (MP) intake was 6.6, 8.3, 7.9 and $7.9 \mathrm{MJ} /$ day and 64.0, 80.0, 76.0 and $76.0 \mathrm{~g} /$ day for $\mathrm{T}_{1}, \mathrm{~T}_{2}, \mathrm{~T}_{3}$ and $\mathrm{T}_{4}$, respectively, that served as ME and MP requirement of growing castrated male sheep as recommended in Agriculture and Food Research Council (AFRC, 1995). ME and MP intake of castrated sheep per kg $\mathrm{W}^{0.75}$ was significantly $(\mathrm{P}<0.05)$ decreased with increasing age (Table 3$)$. ME and MP requirements of castrated male sheep per $\mathrm{kg}$ metabolic weight were the highest $\left(999.0 \mathrm{KJ} / \mathrm{kg} \mathrm{W}^{0.75}\right.$ and $9.6 \mathrm{~g} /$ day, respectively) in younger than others groups followed by 828,806 and $725 \mathrm{KJ} / \mathrm{kg} \mathrm{W} \mathrm{W}^{0.75}$ and $8.9,7.7$ and 7.0 for $\mathrm{T}_{2}, \mathrm{~T}^{3}$ and $\mathrm{T}_{4}$, respectively.

Table 2. Body weight gain, FCR and cost of feeding for one $\mathrm{kg}$ meat production at different ages of castrated sheep

\begin{tabular}{l|c|c|c|c|cc}
\hline \multirow{2}{*}{ Parameters } & \multicolumn{4}{c|}{ Treatments (Mean \pm SE) } & \multicolumn{2}{c}{ Significant } \\
\cline { 2 - 8 } & $\mathrm{T}_{1}$ & $\mathrm{~T}_{2}$ & $\mathrm{~T}_{3}$ & $\mathrm{~T}_{4}$ & SED & Level \\
\hline Initial live weight $(\mathrm{kg})$ & $12.9^{\mathrm{a}} \pm 1.5$ & $18.7^{\mathrm{b}} \pm 0.9$ & $21.0^{\mathrm{c}} \pm 1.6$ & $24.3^{\mathrm{d}} \pm 0.6$ & 1.21 & $* * *$ \\
Final Live weight $(\mathrm{kg})$ & $17.7^{\mathrm{a}} \pm 1.6$ & $22.6^{\mathrm{b}} \pm 0.6$ & $24.3^{\mathrm{c}} \pm 1.8$ & $24.9^{\mathrm{d}} \pm 0.6$ & 1.26 & $* * *$ \\
ADG (g/day) & $79.3^{\mathrm{a}} \pm 5.3$ & $63.3^{\mathrm{ab}} \pm 0.8$ & $54.6^{\mathrm{ab}} \pm 6.2$ & $44.0^{\mathrm{c}} \pm 3.9$ & 6.32 & $*$ \\
FCR & $9.2^{\mathrm{a}} \pm 1.5$ & $13.8^{\mathrm{b}} \pm 1.6$ & $17.7^{\mathrm{c}} \pm 2.5$ & $21.7^{\mathrm{d}} \pm 1.4$ & $1.8^{*}$ & $* * *$ \\
\hline
\end{tabular}

Cost of feeding for $1 \mathrm{~kg}$ meat production

$\begin{array}{lllll}\text { Cost of feed } / \mathrm{kg} \text { meat } \quad 239.0^{\mathrm{a}} & 357.0^{\mathrm{b}} \quad 440.0^{\mathrm{c}} & 515.0^{\mathrm{d}} & 9.2 & \\ & & & \end{array}$ (1 kg Taka)

$* * *=$ Significant at $0.1 \%$ level $; * *=$ Significant at $1 \%$ level; $*=$ Significant at $5 \%$ level; NS $=$ Not significant; $a, b, c=$ mean value with different superscripts within rows differ significant at $\mathrm{P}<0.05$

Table 3. Daily intake of feed nutrient by castrated sheep at different ages

\begin{tabular}{|c|c|c|c|c|c|c|}
\hline \multirow[t]{2}{*}{ Parameters } & \multicolumn{4}{|c|}{ Treatments } & \multicolumn{2}{|c|}{ Treatments } \\
\hline & $\mathrm{T}_{1}$ & $\mathrm{~T}_{2}$ & $\mathrm{~T}_{3}$ & $\mathrm{~T}_{4}$ & SED & Level \\
\hline TDMI (g/d) & $725.0 \mathrm{a} \pm 61.8$ & $943.0^{\mathrm{b}} \pm 19.7$ & $956.0^{\mathrm{b}} \pm 24.6$ & $914.0^{\mathrm{b}} \pm 48.7$ & 42.24 & * \\
\hline CDMI $(g / d)$ & $184.0^{a} \pm 9.2$ & $243.0^{\mathrm{b}} \pm 9.6$ & $262.0^{\mathrm{b}} \pm 23.6$ & $288.0^{\mathrm{b}} \pm 15.2$ & 15.50 & * \\
\hline DM intake $\left(\mathrm{g} / \mathrm{kgW}^{0.75}\right)$ & $11.0 \mathrm{a} \pm 9.8$ & $105.0^{\mathrm{b}} \pm 4.3$ & $99.0^{\mathrm{b}} \pm 3.2$ & $84.0^{\mathrm{b}} \pm 4.9$ & 6.21 & * \\
\hline $\operatorname{RDMI}(\mathrm{g} / \mathrm{d})$ & $540.0^{a} \pm 55.8$ & $699.0^{\mathrm{b}} \pm 14.6$ & $693.0^{\mathrm{b}} \pm 11.4$ & $625.0^{\mathrm{b}} \pm 36.9$ & 37.72 & * \\
\hline$\%$ concentrate of TDMI & $26.0^{\mathrm{a}} \pm 1.8$ & $26.0^{a} \pm 0.7$ & $27.0^{\mathrm{a}} \pm 1.9$ & $32.0^{\mathrm{b}} \pm 1.2$ & 1.42 & * \\
\hline DMI \%LW & $4.2^{\mathrm{b}} \pm 0.4$ & $4.2 \mathrm{~b} \pm 0.1$ & $4.0^{\mathrm{b}} \pm 0.2$ & $3.4^{a} \pm 0.2$ & 0.27 & * \\
\hline ME intake $(\mathrm{MJ} / \mathrm{d})$ & $6.6 \pm 0.7$ & $8.3 \pm 0.3$ & $7.9 \pm 0.5$ & $7.9 \pm 0.7$ & 0.56 & NS \\
\hline MP intake $(g / d)$ & $64.0 \pm 6.2$ & $80.0 \pm 3.1$ & $76.0 \pm 4.4$ & $76.0 \pm 6.9$ & 5.36 & NS \\
\hline ME intake (KJ/kg W0.75) & $999.0^{b} \pm 97.0$ & $828.0^{a} \pm 54.3$ & $806^{\mathrm{a}} \cdot 0 \pm 18.8$ & $725.0^{a} \pm 70.6$ & 66.60 & * \\
\hline MP intake $\left(\mathrm{g} / \mathrm{kg} \mathrm{W}^{0.75}\right)$ & $9.59 \mathrm{~b} \pm 0.9$ & $8.91^{\mathrm{b}} \pm 0.5$ & $7.73^{a} \pm 0.2$ & $6.96^{\mathrm{a}} \pm 0.7$ & 0.63 & * \\
\hline
\end{tabular}

* = Significant at $5 \%$ level; NS = Not significant; $\mathrm{a}, \mathrm{b}, \mathrm{c}=$ Mean value with different superscripts within rows differ significant at $\mathrm{P}<0.05$ 
For each gram increased in $\mathrm{LW}$ gain, it required $7.7 \mathrm{KJ} \mathrm{ME}$ and at animals achieved zero LW gain (maintenance energy level) at $377 \mathrm{KJ} / \mathrm{kg} \mathrm{W} \mathrm{W}^{0.75} /$ day $\mathrm{ME}$ intake (Fig. 1).

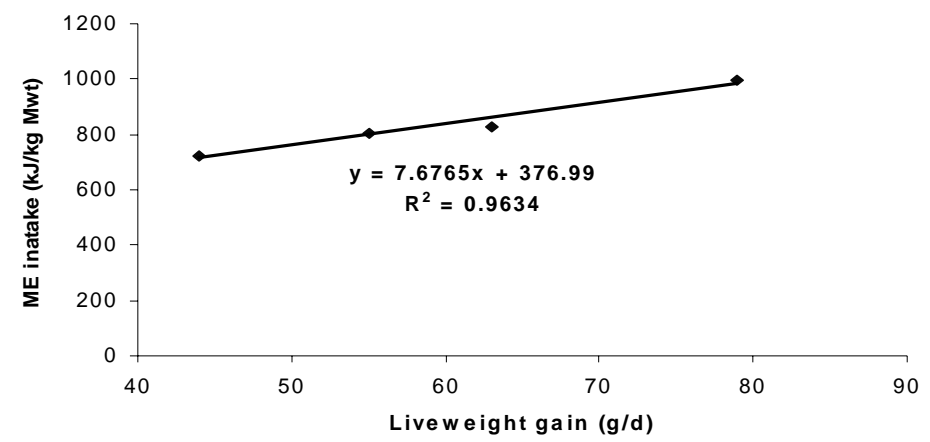

Fig. 1. Regression between ME intake and live weight gain for different age group of Native sheep

\section{Nutrient utilization}

The nutrient utilization of same plane of nutrition supplied to castrated sheep of different age groups or in different LW is shown in Table 4. Age or LW differences had no significant $(\mathrm{P}>0.05)$ effects on the total digestibly of DM $(66,67,65,67), \mathrm{CP}$ $(52,49,46,47)$ and organic matter (OM; 59, 69, 66, 66), respectively.

Table 4. Digestibility (\%) and N-balance of castrated native sheep at different ages

\begin{tabular}{|c|c|c|c|c|c|c|}
\hline \multirow[t]{2}{*}{ Parameters } & \multicolumn{4}{|c|}{ Treatments } & \multirow[t]{2}{*}{ SED } & \multirow[t]{2}{*}{ Level } \\
\hline & $\mathrm{T}_{1}$ & $\mathrm{~T}_{2}$ & $\mathrm{~T}_{3}$ & $\mathrm{~T}_{4}$ & & \\
\hline \multicolumn{7}{|l|}{ Digestibility (\%) } \\
\hline DM digestibility & $66.0 \pm 2.6$ & $67.0 \pm 1.8$ & $65.0 \pm 2.7$ & $67.0 \pm 3.3$ & 2.70 & NS \\
\hline $\mathrm{CP}$ digestibility & $52.0 \pm 3.9$ & $49.0 \pm 2.3$ & $46.0 \pm 3.4$ & $47.0 \pm 4.4$ & 3.59 & NS \\
\hline ADF digestibility & $63.0^{\mathrm{a}} \pm 3.4$ & $68.0^{a} \pm 1.8$ & $88.0^{\mathrm{b}} \pm 1.0$ & $81.0^{\mathrm{b}} \pm 2.4$ & 2.33 & * \\
\hline OM digestibility & $59.0 \pm 2.5$ & $69.0 \pm 2.0$ & $66.0 \pm 2.0$ & $66.0 \pm 2.7$ & 3.27 & NS \\
\hline \multicolumn{7}{|l|}{ N-balance } \\
\hline N-intake (mg/kg W0.75) & $1248.0^{\mathrm{b}} \pm 10.6$ & $1243.0^{b} \pm 26.0$ & $1169.0^{b} \pm 69.0$ & $986.0^{\mathrm{a}} \pm 49.0$ & 69.09 & * \\
\hline $\begin{array}{l}\text { N-excretion in feces } \\
\left(\mathrm{mg} / \mathrm{kg} \mathrm{W}^{0.75}\right)\end{array}$ & $603.0 \pm 74.0$ & $617.0 \pm 30.8$ & $636.0 \pm 63.0$ & $507.0 \pm 21.3$ & 52.09 & NS \\
\hline $\begin{array}{l}\text { N-excretion in urine } \\
\left(\mathrm{mg} / \mathrm{kg} \mathrm{W}^{0.75}\right)\end{array}$ & $154.0 \pm 15.2$ & $174.0 \pm 13.0$ & $170.0 \pm 10.4$ & $170.0 \pm 10.4$ & 17.76 & NS \\
\hline $\begin{array}{l}\text { Total N-excretion } \\
\left(\mathrm{mg} / \mathrm{kg} \mathrm{W}^{0.75}\right)\end{array}$ & $748.0 \pm 69.5$ & $791.0 \pm 43.2$ & $831.0 \pm 72.0$ & $687.0 \pm 72.0$ & 55.25 & NS \\
\hline $\begin{array}{l}\text { N-balance }(\mathrm{mg} / \mathrm{kg} \\
\left.\mathrm{W}^{0.75}\right)\end{array}$ & $500.0^{\mathrm{b}} \pm 61.3$ & $452.0^{\mathrm{b}} \pm 30.2$ & $338.0^{a} \pm 30.2$ & $309.0^{a} \pm 53.2$ & 52.57 & * \\
\hline N-retention (\%) & $40.0 \pm 2.8$ & $36.0 \pm 4.3$ & $29.0 \pm 3.2$ & $30.0 \pm 4.1$ & 3.64 & * \\
\hline
\end{tabular}

$* * *=$ Significant at $0.1 \%$ level; $* *=$ Significant at $1 \%$ level; ${ }^{*}=$ Significant at $5 \%$ level; NS $=$ Not significant; $\mathrm{a}, \mathrm{b}, \mathrm{c}=$ mean value with different superscripts within rows differ significant at $\mathrm{P}<0.05$ 
Digestibility of acid detergent fibre $(\mathrm{ADF})$ was significantly $(\mathrm{P}<0.01)$ higher $(88 \%)$ in $\mathrm{T}_{3}$ as compared to $\mathrm{T}_{1}$ and $\mathrm{T}_{2}$ but not significant $(\mathrm{P}>0.05)$ in $\mathrm{T}_{4}$. Nitrogen $(\mathrm{N})$ intake $\left(\mathrm{mg} / \mathrm{kg} \mathrm{W} \mathrm{W}^{0.75}\right)$ was significantly $(\mathrm{P}<0.05)$ higher $(1248,1243$ and 1169$)$ in $\mathrm{T}_{1}, \mathrm{~T}_{2}$ and $\mathrm{T}_{3}$ than $\mathrm{T}_{4}$ (986). No difference was detected in faecal $\mathrm{N}$, urinary $\mathrm{N}$ and total $\mathrm{N}$ excretion. N-balanced was significantly $(\mathrm{P}<0.05)$ higher $\left(500 \& 452 \mathrm{mg} / \mathrm{kg} \mathrm{W} \mathrm{W}^{0.7}\right)$ in $\mathrm{T}_{1}$ and $\mathrm{T}_{2}$, respectively, than $\mathrm{T}_{3}$ and $\mathrm{T}_{4}\left(338 \& 309 \mathrm{mg} / \mathrm{kg} \mathrm{W} \mathrm{W}^{0.7}\right)$, respectively. N-retention $(\%)$ as percentage of $\mathrm{N}$-intake was significantly $(\mathrm{P}<0.01)$ higher $(40 \%)$ in the younger group than that of the other three groups.

\section{Pre slaughter body measurement}

Pre-slaughter measurement of castrated native sheep is presented in Table 5. Except chest depth, all parameters were significantly higher in $\mathrm{T}_{2}, \mathrm{~T}_{3}$ and $\mathrm{T}_{4}$ than that of $\mathrm{T}_{1}$. Hearth girth $(\mathrm{P}<0.01)$, shoulder height $(\mathrm{P}<0.05)$, body length from body to shoulder and height at hind length was increased with the increase of age or body weight.

Table 5. Effects of ages on body measurements of native castrated sheep

\begin{tabular}{|c|c|c|c|c|c|c|}
\hline \multirow[t]{2}{*}{ Parameters } & \multicolumn{4}{|c|}{ Treatments } & \multirow[t]{2}{*}{ SED } & \multirow[t]{2}{*}{ Level } \\
\hline & $\mathrm{T}_{1}$ & $\mathrm{~T}_{2}$ & $\mathrm{~T}_{3}$ & $\mathrm{~T}_{4}$ & & \\
\hline Hearth girth $(\mathrm{cm})$ & $63.4^{a} \pm 1.3$ & $70.0^{\mathrm{b}} \pm 1.8$ & $71.0^{b} \pm 3.5$ & $76.0^{\mathrm{b}} \pm 1.0$ & 2.11 & ** \\
\hline Shoulder height $(\mathrm{cm})$ & $51.0^{\mathrm{a}} \pm 1.3$ & $56.0^{\mathrm{b}} \pm 1.0$ & $56.0^{\mathrm{b}} \pm 1.1$ & $57.0^{\mathrm{b}} \pm 1.3$ & 1.17 & * \\
\hline Body length $(\mathrm{cm})$ & $52.0^{a} \pm 2.2$ & $57.0^{\mathrm{b}} \pm 0.8$ & $58.0^{\mathrm{b}} \pm 1.8$ & $61.0^{\mathrm{b}} \pm 0.7$ & 1.52 & * \\
\hline Chest depth $(\mathrm{cm})$ & $21.0 \pm 0.4$ & $21.0 \pm 0.8$ & $21.0 \pm 0.3$ & $22.0 \pm 0.5$ & 0.51 & NS \\
\hline Height at hind length $(\mathrm{cm})$ & $52.0^{\mathrm{a}} \pm 1.2$ & $58.0^{\mathrm{b}} \pm 1.1$ & $59.0^{\mathrm{b}} \pm 0.8$ & $60.0^{\mathrm{b}} \pm 1.0$ & 1.01 & ** \\
\hline
\end{tabular}

*** $=$ Significant at $0.1 \%$ level; $* *=$ Significant at $1 \%$ level; $*=$ Significant at $5 \%$ level; NS $=$ Not significant; $a, b, c=$ mean value with different superscripts within rows differ significant at $\mathrm{P}<0.05$

\section{Carcass yield and its characteristics}

The average live weight of castrated sheep of different groups was 18.6, 22.6, 24.2 and 25.7 for $T_{1}, T_{2}, T_{3}$ and $T_{4}$ before slaughter, respectively. Warm carcass weight was 9.0, 11.0, 12.4 and $14.2 \mathrm{~kg}$ for $\mathrm{T}_{1}, \mathrm{~T}_{2}, \mathrm{~T}_{3}$ and $\mathrm{T}_{4}$, respectively (Table 6). Live weight at slaughter was significantly $(\mathrm{P}<0.05)$ lower in $\mathrm{T}_{1}$ compare to $\mathrm{T}_{2}, \mathrm{~T}_{3}$ and $\mathrm{T}_{4}$. Warm carcass weight was significantly $(\mathrm{P}<0.001)$ increased linearly $\left(\mathrm{r}^{2}=0.995\right)$ with increasing age. Dressing percentage was significantly $(\mathrm{P}<0.01)$ higher $(55.5 \%)$ in the older group $\left(\mathrm{T}_{4}\right)$ than others three group as $48.5 \%, 49.0 \%$ and $51.4 \%$, respectively. It is indicated that dressing percentage was increased with increasing of age. Dressing percentage is both yielding and value determining factor and is therefore, an important parameter in assessing performance of meat producing animals. Whole digestive tract with content as \% LW was significantly $(\mathrm{P}<0.01)$ lower $(13.2 \%)$ in the older group $\left(\mathrm{T}_{4}\right)$ but there is no significance difference $(21.7 \& 21.2 \%)$ among two younger $\left(T_{1} \& T_{2}\right)$ groups, respectively. The result agreed with Huque et al. (2007). GI content of percent LW was significantly $(\mathrm{P}<0.05)$ higher $(18.1 \%)$ in $\mathrm{T}_{4}$ and lower 
$(12.1 \%)$ in $\mathrm{T}_{3}$ but similar percent $(15 \%)$ weight was in $\mathrm{T}_{1}$ and $\mathrm{T}_{2}$. Fat deposition in different parts of the body (as \% LW \& as \%WC) like caul and gut fat, kidney and channel fat, heart fat and subcutaneous fats is presented in Table 6. Caul and gut fat was significantly higher $(6.9 \& 8.0 \%)$ in $\mathrm{T}_{3}$ and $\mathrm{T}_{4}$, respectively, than younger group.

Table 6. Effects of ages on carcass characteristics of castrated native sheep

\begin{tabular}{|c|c|c|c|c|c|c|}
\hline \multirow[t]{2}{*}{ Parameters } & \multicolumn{4}{|c|}{ Treatments } & \multirow[t]{2}{*}{ SED } & \multirow[t]{2}{*}{ Level } \\
\hline & $\mathrm{T}_{1}$ & $\mathrm{~T}_{2}$ & $\mathrm{~T}_{3}$ & $\mathrm{~T}_{4}$ & & \\
\hline LW at slaughter (kg) & $18.6^{\mathrm{a}} \pm 1.3$ & $22.6^{\mathrm{b}} \pm 0.6$ & $24.2^{b} \pm 1.7$ & $25.7 \mathrm{~b} \pm 0.7$ & 1.14 & * \\
\hline Warm carcass $(\mathrm{kg})$ & $9.0^{\mathrm{a}} \pm 0.6$ & $11.0^{\mathrm{b}} \pm 0.4$ & $12.4^{b} \pm 0.9$ & $14.2^{c} \pm 0.5$ & $0 . .61$ & $* * *$ \\
\hline Dressing $(\%)$ & $48.5^{\mathrm{a}} \pm 0.4$ & $49.0^{\mathrm{a}} \pm 0.7$ & $51.4^{\mathrm{a}} \pm 1.6$ & $55.5^{\mathrm{b}} \pm 0.7$ & 0.97 & ** \\
\hline \multicolumn{7}{|l|}{ Gastrointestinal tract } \\
\hline GI tract weight (\%LW) & $21.7^{c} \pm 0.6$ & $21.2^{c} \pm 0.6$ & $19.2^{\mathrm{b}} \pm 1.4$ & $13.2^{\mathrm{a}} \pm 0.4$ & 0.86 & $* *$ \\
\hline Empty digestive tract (\%) & $6.9 \pm 0.4$ & $6.0 \pm 1.5$ & $7.0 \pm 0.2$ & $5.1 \pm 0.3$ & 0.66 & NS \\
\hline GI tract content (\% LW) & $15.0^{a} \pm 0.8$ & $15.0^{\mathrm{a}} \pm 1.3$ & $12.1^{\mathrm{b}} \pm 1.3$ & $18.1^{c} \pm 0.3$ & 0.99 & * \\
\hline Intestine length $(\mathrm{ft})$ & $70.0^{\mathrm{b}} \pm 1.6$ & $68.0 \pm 1.9$ & $66.0 \pm 1.2$ & $64.0^{\mathrm{a}} \pm 1.2$ & 1.49 & * \\
\hline \multicolumn{7}{|l|}{ Out of total carcass fat } \\
\hline Caul \& gut fat (\%LW) & $2.2^{\mathrm{a}} \pm 0.4$ & $3.3^{a} \pm 0.5$ & $6.9^{\mathrm{b}} \pm 1.2$ & $8.0^{\mathrm{b}} \pm 0.6$ & 0.74 & $* * *$ \\
\hline Heart fat $(\% \mathrm{LW})$ & $0.1^{\mathrm{a}} \pm 0.0$ & $0.2^{\mathrm{b}} \pm 0.0$ & $0.3^{c} \pm 0.0$ & $0.4^{\mathrm{d}} \pm 0.0$ & 0.024 & $* * *$ \\
\hline Kidney and channel fat (\% LW) & $1.1^{\mathrm{a}} \pm 0.2$ & $1.6^{\mathrm{a}} \pm 0.4$ & $2.4^{\mathrm{b}} \pm 0.3$ & $4.3^{c} \pm 0.5$ & 0.36 & $* * *$ \\
\hline Subcutaneous fat (\% LW) & $2.2^{\mathrm{a}} \pm 0.3$ & $2.6^{\mathrm{a}} \pm 0.5$ & $5.9^{\mathrm{b}} \pm 0.6$ & $7.8^{c} \pm 0.1$ & 0.41 & $* * *$ \\
\hline Subcutaneous fat (\% WC) & $4.5^{a} \pm 0.5$ & $5.3^{\mathrm{a}} \pm 1.0$ & $11.3^{b} \pm 0.9$ & $14.0^{c} \pm 0.2$ & 0.72 & $* * *$ \\
\hline Total fat (\% LW) & $5.6^{\mathrm{a}} \pm 0.8$ & $7.7^{\mathrm{a}} \pm 1.2$ & $15.5^{\mathrm{b}} \pm 0.6$ & $20.6^{c} \pm 0.8$ & 1.08 & $* * *$ \\
\hline
\end{tabular}

$* * *=$ Significant at $0.1 \%$ level; ${ }^{* *}=$ Significant at $1 \%$ level; ${ }^{*}=$ Significant at $5 \%$ level; NS $=$ Not significant; $\mathrm{a}, \mathrm{b}, \mathrm{c}=$ mean value with different superscripts within rows differ significant $\mathrm{at} \mathrm{P}<0.05$

The fat surrounded the heart was linearly $\left(\mathrm{r}^{2}=0.98\right)$ increased resulting significant $(\mathrm{P}<0.001)$ difference among different treatment groups. Kidney and channel fat significantly $(\mathrm{P}<0.001)$ higher $(5.9 \% \& 7.8 \%)$ in $\mathrm{T}_{3}$ and $\mathrm{T}_{4}$ than in $\mathrm{T}_{1}(1.1 \%)$ and $\mathrm{T}_{2}(1.6 \%)$. Subcutaneous fat both as $\% \mathrm{LW}$ and warm carcass weight and total fat as \% LW were followed similar trend to kidney and channel fat.

The results indicated that the greatest change in proportions of various fat depots occurred from nine month of age. The results in terms of visceral fat was supported by Chowdhury and Faruque (2004), who described that up to six months visceral fat content was about $1.2 \%$ of LW that increased to about 5\% during $180-365$ days and $6 \%$ for animals over one years old. Fat depots increase following order of increasing rate subcutaneous, gut and caul fat, heart and kidney and channel fat. These findings are supported to Ladipo (1973). 


\section{Primal cut}

Primal cut, non-carcass edible components and non-carcass non-edible components are shown in Table 7. The result of primal cut was expressed as percent of warm or hot carcass. Neck, shoulder, rack, short loin, fore shank, tender loin and breast and flap comprises in the forequarter. Neck is significantly $(\mathrm{P}<0.05)$ higher $(5.9 \%)$ in the youngest group and decreased gradually (5.0, $3.9 \& 3.6 \%$, respectively) with the increasing age. Rack as percent of warm carcass was significantly $(\mathrm{P}<0.001)$ higher $(7.6 \%)$ in the youngest group than other three group $(6.7 \%, 6.9 \% \& 6.9 \%$, respectively).

Table 7. Effects of ages on prim cut of native sheep

\begin{tabular}{|c|c|c|c|c|c|c|}
\hline \multirow[t]{2}{*}{ Parameters } & \multicolumn{4}{|c|}{ Ages (months) } & \multicolumn{2}{|c|}{ Significant } \\
\hline & $>3$ to $\leq 6$ & $>6$ to $\leq 9$ & $>9$ to $\leq 12$ & $>12$ to $\leq 15$ & SED & Level \\
\hline \multicolumn{7}{|l|}{ Primal cut } \\
\hline Warm carcass (kg) & $9.0^{a} \pm 0.6$ & $11.0^{\mathrm{b}} \pm 0.4$ & $12.4^{b} \pm 0.9$ & $14.2^{c} \pm 0.5$ & 0.61 & $* * *$ \\
\hline \multicolumn{7}{|l|}{ Fore quarter } \\
\hline Neck (\% WC) & $5.3^{\mathrm{b}} \pm 0.4$ & $5.0^{\mathrm{b}} \pm 0.4$ & $3.9^{\mathrm{a}} \pm 0.4$ & $3.6^{a} \pm 0.1$ & 0.33 & * \\
\hline Shoulder (\% WC) & $17.3 \pm 0.7$ & $17.3 \pm 0.7$ & $17.2 \pm 0.9$ & $16.5 \pm 1.1$ & 0.87 & NS \\
\hline Rack (\% WC) & $7.6^{b} \pm 0.1$ & $6.7 \mathrm{a} \pm 0.4$ & $6.9^{a} \pm 0.5$ & $6.9 \mathrm{a} \pm 0.5$ & 0.29 & $* * *$ \\
\hline Short loin (\% WC) & $8.7^{a} \pm 0.4$ & $9.0^{\mathrm{a}} \pm 1.0$ & $9.3^{\mathrm{a}} \pm 1.0$ & $11.5^{\mathrm{b}} \pm 1.0$ & 1.09 & $* * *$ \\
\hline Fore shank (\% WC) & $2.8 \pm 0.1$ & $2.8 \pm 0.2$ & $2.5 \pm 0.1$ & $2.6 \pm 0.3$ & 0.19 & NS \\
\hline Tender loin (\% WC) & $1.5^{\mathrm{b}} \pm 0.1$ & $1.1^{\mathrm{ab}} \pm 0.1$ & $0.8^{a} \pm 0.3$ & $0.9 \mathrm{a} \pm 0.1$ & 0.20 & $* * *$ \\
\hline Breast \& Flap (\% WC) & $18.7 \pm 0.8$ & $19.6 \pm 0.6$ & $18.7 \pm 0.9$ & $18.0 \pm 0.5$ & 0.73 & NS \\
\hline \multicolumn{7}{|l|}{ Hind quarter } \\
\hline Leg chump (\% WC) & $24.4 \pm 0.8$ & $24.1 \pm 0.4$ & $22.5 \pm 1.3$ & $22.9 \pm 0.9$ & 0.92 & NS \\
\hline Hind shank (\% WC) & $5.1^{b} \pm 0.2$ & $4.7 \mathrm{~b} \pm 0.2$ & $4.1^{\mathrm{a}} \pm 0.2$ & $4.0^{\mathrm{a}} \pm 0.2$ & 0.19 & * \\
\hline \multicolumn{7}{|l|}{ Non-carcass edible components } \\
\hline Liver (\% LW) & $1.5^{\mathrm{b}} \pm 0.1$ & $1.4^{\mathrm{ab}} \pm 0.1$ & $1.2^{\mathrm{a}} \pm 0.1$ & $1.3^{\mathrm{ab}} \pm 0.0$ & 0.07 & * \\
\hline Kidney (\%LW) & $0.3^{a} \pm 0.0$ & $0.3^{\mathrm{a}} \pm 0.0$ & $0.2^{\mathrm{b}} \pm 0.0$ & $0.2^{\mathrm{b}} \pm 0.0$ & 0.02 & * \\
\hline Lung with trachea (\% LW) & $1.4 \pm 0.1$ & $1.2 \pm 0.1$ & $1.1 \pm 0.1$ & $1.2 \pm 0.1$ & 0.08 & NS \\
\hline Spleen (\% LW) & $0.3^{b} \pm 0.0$ & $0.3^{b} \pm 0.0$ & $0.3^{b} \pm 0.0$ & $0.2^{\mathrm{a}} \pm 0.0$ & 0.03 & * \\
\hline \multicolumn{7}{|c|}{ Non carcass non-edible components } \\
\hline Blood (\% LW) & $8.0^{\mathrm{b}} \pm 0.5$ & $4.0^{\mathrm{a}} \pm 0.2$ & $3.5^{\mathrm{a}} \pm 0.2$ & $3.3^{a} \pm 0.1$ & 0.27 & $* * *$ \\
\hline Skin $(\% \mathrm{LW})$ & $7.5^{a} \pm 0.2$ & $8.7^{b} \pm 0.4$ & $8.0^{\mathrm{a}} \pm 0.2$ & $7.7 \mathrm{a} \pm 0.3$ & 0.26 & * \\
\hline Four paya $(\% \mathrm{LW})$ & $1.2^{\mathrm{a}} \pm 0.2$ & $1.8 \mathrm{ab} \pm 0.1$ & $2.2^{b} \pm 0.4$ & $2.3^{b} \pm 0.2$ & 0.07 & * \\
\hline
\end{tabular}

$* * *=$ Significant at $0.1 \%$ level; $* *=$ Significant at $1 \%$ level; ${ }^{*}=$ Significant at $5 \%$ level; NS $=$ Not significant; $\mathrm{a}, \mathrm{b}, \mathrm{c}=$ mean value with different superscripts within rows differ significant at $\mathrm{P}<0.05$ 
Tender loin followed similar trend to rack cut. On the other hand, short loin was significantly highest (11.5\%) in the older compares to others three groups. As part of total carcass, the proportional yield of tender loin and hind leg chump the most valued retail cut decreased with the increase of animal age (Table 7). The hindquarter includes leg chump and hind shank. Leg chump was non-significantly $(\mathrm{P}>0.05)$ higher in younger groups than older groups (Table 7). Hind shank was significantly $(\mathrm{P}<0.5)$ higher $(5.1 \& 4.7 \%$, respectively) in younger than older group $(4.1 \& 4.0 \%)$, respectively. Non-carcass edible components like liver, kidney, lung with trachea and spleen is presented in Table 7. Except lung with trachea, others three components; liver, kidney and spleen as percent warm carcass was significantly $(\mathrm{P}<0.05)$ higher $\left(1.5,0.3 \& 0.3 \%\right.$, respectively) in $\mathrm{T}_{1}$ compare to other three groups.

The results of the present study corroborated the finding of Chowdhury and Faruque, (2004) on goats live on green grass based and Huque et al. (2007) on cattle on silage based ration. Effects of age on non-carcass non-edible parts are shown in Table 7. Blood, skin and four paya were presented as a percent LW. Blood as percent of $\mathrm{LW}$ was significantly $(\mathrm{P}<0.001)$ higher $(8.0 \%)$ in $\mathrm{T}_{1}$ but it decreased $(4.0,3.5 \& 3.3 \%$, respectively) with increasing age. This finding is supported by Cowdhury and Faruque (2004); Huque et al. (2007). Skin was significantly $(\mathrm{P}<0.05)$ higher $(8.7 \%$ of $\mathrm{LW}$ ) in $\mathrm{T}_{2}$ than that of $8.0,7.7$ and $7.5 \%$ in $\mathrm{T}_{3}, \mathrm{~T}_{4}$ and $\mathrm{T}_{1}$, respectively. Four paya as percent LW was significantly $(\mathrm{P}<0.05)$ higher $(2.3 \%)$ in the older group $\left(\mathrm{T}_{4}\right)$ and it increased with the advancement of age.

\section{Chemical composition of meat}

Effects of age on chemical composition of some carcass cuts are given in Table 8. Dry matter content of shoulder, tender loin, eye muscle, leg chump and short loin was significantly $(\mathrm{P}<0.05)$ increased with age. These findings supported the Chowdhury and Faruque (2004). The protein content of shoulder, tender loin, eye muscle and leg chump was significantly $(\mathrm{P}<0.05)$ higher in both $\mathrm{T}_{1}$ and $\mathrm{T}_{2}$ than $\mathrm{T}_{3}$ and $\mathrm{T}_{4}$. Except short loin protein content was gradually increased with the increasing of age. These results were supported to Chowdhury and Faruque (2004) on goat meat. Ash content in different primary cut was followed the $\mathrm{CP}$ content except tenderloin (Table 8). It is mentioned that subcutaneous fat was trimmed out.

In shoulder cut, there was no significance difference in fat content among various age groups. Without subcutaneous fat, fat percent in tender loin, eye muscle,

and leg chump was significantly increased with the advancement of age. The fat content was almost inter-muscular. The mean fat content was higher in the eye muscle $(11.9 \%)$ then followed leg chump $(9.0 \%)$, tender loin $(7.5 \%)$, shoulder $(6.0 \%)$ and short loin $(5.0 \%)$. 
Table 8. Chemical composition of some carcass cuts of Native castrated sheep at different ages

\begin{tabular}{|c|c|c|c|c|c|c|}
\hline \multirow[t]{2}{*}{ Parameters } & \multicolumn{4}{|c|}{ Treatments groups } & \multicolumn{2}{|c|}{ Significant } \\
\hline & $\mathrm{T}_{1}$ & $\mathrm{~T}_{2}$ & $\mathrm{~T}_{3}$ & $\mathrm{~T}_{4}$ & SED & Level \\
\hline \multicolumn{7}{|l|}{ Shoulder } \\
\hline $\mathrm{DM} \%$ & $31.0^{\mathrm{a}} \pm 1.6$ & $28.0^{\mathrm{a}} \pm 1.7$ & $34.0^{\mathrm{b}} \pm 1.1$ & $32.0^{\mathrm{b}} \pm 1.3$ & 1.42 & * \\
\hline $\mathrm{CP} \%$ & $60.0^{\mathrm{ab}} \pm 4.3$ & $68.0^{\mathrm{b}} \pm 5.0$ & $55.0^{\mathrm{a}} \pm 2.3$ & $57.0^{\mathrm{a}} \pm 3.2$ & 3.9 & * \\
\hline Ash \% & $3.2 \pm 0.9$ & $4.1 \pm 0.2$ & $3.0 \pm 0.8$ & $3.0 \pm 0.3$ & 0.63 & NS \\
\hline $\mathrm{EE} \%$ & $5.6 \pm 1.3$ & $5.6 \pm 0.8$ & $6.0 \pm 0.9$ & $6.8 \pm 0.7$ & 0.95 & NS \\
\hline \multicolumn{7}{|l|}{ Tender loin } \\
\hline $\mathrm{DM} \%$ & $26.0^{\mathrm{a}} \pm 1.7$ & $30.0^{\mathrm{a}} \pm 1.9$ & $34.0^{\mathrm{b}} \pm 1.8$ & $36.0^{\mathrm{b}} \pm 2.5$ & 1.9 & * \\
\hline $\mathrm{CP} \%$ & $62.0 \pm 4.3$ & $66.0 \pm 4.4$ & $61.0 \pm 4.0$ & $62.0 \pm 3.1$ & 3.9 & NS \\
\hline Ash\% & $2.0 \pm 0.3$ & $3.0 \pm 0.8$ & $4.0 \pm 0.8$ & $2.0 \pm 0.1$ & 0.61 & NS \\
\hline $\mathrm{EE} \%$ & $3.8^{\mathrm{a}} \pm 0.3$ & $6.5^{b} \pm 0.7$ & $9.6^{c} \pm 0.7$ & $10.0^{c} \pm 0.8$ & 0.62 & $* * *$ \\
\hline \multicolumn{7}{|l|}{ Eye muscle } \\
\hline DM\% & $30.0^{\mathrm{a}} \pm 1.4$ & $29.0^{\mathrm{a}} \pm 1.9$ & $38.0^{\mathrm{b}} \pm 2.9$ & $43.0^{\mathrm{b}} \pm 7.9$ & 4.36 & * \\
\hline $\mathrm{CP} \%$ & $69.0^{\mathrm{b}} \pm 2.0$ & $74.0^{\mathrm{b}} \pm 1.1$ & $58.0^{\mathrm{a}} \pm 3.7$ & $59.0^{\mathrm{a}} \pm 1.9$ & 2.45 & $* *$ \\
\hline Ash\% & $3.0^{\mathrm{b}} \pm 0.4$ & $4.0^{\mathrm{b}} \pm 0.3$ & $2.0^{\mathrm{a}} \pm 0.3$ & $2.0^{\mathrm{a}} \pm 0.2$ & 0.33 & * \\
\hline $\mathrm{EE} \%$ & $6.7^{a} \pm 0.5$ & $10.8^{\mathrm{b}} \pm 1.6$ & $14.2^{\mathrm{c}} \pm 1.1$ & $15.4^{\mathrm{cd}} \pm 1.4$ & 1.2 & $* * *$ \\
\hline \multicolumn{7}{|l|}{ Leg chump } \\
\hline DM\% & $31.0^{\mathrm{a}} \pm 1.2$ & $30.0^{\mathrm{a}} \pm 1.5$ & $33.0^{\mathrm{a}} \pm 2.3$ & $37.0^{\mathrm{b}} \pm 3.3$ & 2.3 & * \\
\hline $\mathrm{CP} \%$ & $61.0^{\mathrm{a}} \pm 3.8$ & $70.0^{\mathrm{b}} \pm 3.8$ & $60.0^{\mathrm{a}} \pm 5.0$ & $56.0^{\mathrm{a}} \pm 4.0$ & 2.45 & $* *$ \\
\hline Ash\% & $3.0^{\mathrm{a}} \pm 0.4$ & $4.0^{\mathrm{b}} \pm 0.6$ & $2.4^{\mathrm{a}} \pm 0.7$ & $2.0^{\mathrm{a}} \pm 0.3$ & 0.46 & * \\
\hline $\mathrm{EE} \%$ & $6.0^{\mathrm{a}} \pm 0.6$ & $8.3^{b} \pm 0.8$ & $10.7^{\mathrm{c}} \pm 1.1$ & $10.9^{c} \pm 0.7$ & 0.81 & $* * *$ \\
\hline \multicolumn{7}{|l|}{ Short loin } \\
\hline DM\% & $28.0^{\mathrm{a}} \pm 1.0$ & $33.0^{\mathrm{b}} \pm 2.6$ & $35.0^{\mathrm{b}} \pm 3.0$ & $36.0^{\mathrm{b}} \pm 2.4$ & 2.3 & * \\
\hline $\mathrm{CP} \%$ & $72.0^{\mathrm{b}} \pm 3.4$ & $65.0 \pm 6.0$ & $63.0 \pm 4.0$ & $56.0^{\mathrm{a}} \pm 3.5$ & 4.3 & * \\
\hline Ash\% & $3.3 \pm 0.4$ & $4.5^{\mathrm{b}} \pm 0.5$ & $3.0 \pm 0.7$ & $2.3^{\mathrm{a}} \pm 1.0$ & 0.49 & * \\
\hline $\mathrm{EE} \%$ & $3.5^{\mathrm{a}} \pm 0.2$ & $5.4^{\mathrm{ab}} \pm 0.9$ & $4.6^{\mathrm{ab}} \pm 0.5$ & $6.4^{\mathrm{b}} \pm 0.8$ & 0.66 & * \\
\hline
\end{tabular}

$* * *=$ Significant at $0.1 \%$ level; ${ }^{* *}=$ Significant at $1 \%$ level; $*=$ Significant at $5 \%$ level; NS $=$ Not significant; a,b,c = mean value with different superscripts within rows differ significant at $\mathrm{P}<0.05$

Nutrient intake, growth performance and feed cost per kg production of mutton indicated that body weight gain at early stage (6-8 months of age) of life was more economical than at the later stage of life. It is concluded that the optimum market age of about eight month for native sheep may be achieved when suggested feeding and management condition are maintained. 


\section{References}

AFRC 1995: Energy and Protein Requirements of Ruminants. An advisory manual prepared by the Technical Committee on Responses to Nutrients. By G Alderman and B R Cottrill. United Kingdom.

AOAC 1984: Official of analysis. Association of Official Agricultural Chemists, Washington, DC, USA.

Chowdhury SA, Faruque S 2004: Meat production characteristics of Native Goat. AsianAustralian Journal of Animal Science 17 848-856.

Devendra C, McLeroy GB 1982: Goat and sheep production in the tropics. Intermediate Tropical Agriculture Series, Longman, London, pp. 55.

Dutta, TK, Agnihotri MK, Rao SBN 2007: Effect of supplementation palm oil on nutrient utilization, feeding economics and carcass characteristics in post-weaned Muzafarnagari lambs under feedlot condition. Small Ruminant Research 78 66-73.

Hossain MM, Hashem MA, Hossain MS 1997: Relationship of carcass and non-carcass parameters with live weight of sheep. Bangladesh Journal of Animal Science 26 39-44.

Huque KS, Sultana N, Rahman MZ, Hossain SMJ 2007: Effect of age on feed utilization for growth performances and carcass quality in native bulls. Progressive Agriculture 18 107-116.

Ladipo JK 1973: Body composition of male goats and characterization of their depot fats. PhD Thesis, Cornell University, Ithaca, NY, USA pp. 343.

Mandal A, Singh LB, Raut PK 2000: The Muzaffarnagari sheep : A mutton breed in India. Animal Genetic Resources Information 28 19-25.

Mtenga LA, Kitalyi AJ 1990: Performance and carcass composition of Tanzania goats fed Chloris gayana hay with supplements containing different levels of protein. Small Ruminant Research 3 1-8.

Mukherjee TK 2000: Final Consultancy Report on Goat and Sheep Production. Agriculture Research Management Project (BLRI Part) IDA, Credit No. 2815 BD, Bangladesh Livestock Research Institute, Savar Dhaka-1341, Bangladesh.

Rahman MM 1989: Sheep production and development in Bangladesh. In: Proceedings of the workshop on sheep production in Asia, PACCARD, Los Banos, Philippines pp. 81-95.

Shahjalal MD, Galbraith H, Topps JH 1992: The effect of changes in dietary protein and energy on growth, body composition and Mohair fibre characteristics of British Angora goats. Animal Production 54 405-412.

Singh VK, Karim SA 2003: Emerging trends in meat production from sheep and its export potential. In: Proceedings of the Interaction Seminar on "Meat production and export potential: Impact of globalization and quality concepts," 17 September, Central Institute for Research on Goats, Makhdoom, Farah, Mathura (UP), India pp. 18-30. 